\title{
Pamuk (Gossypium hirsutum L.) genotiplerinin çoklu dizi (line x tester) melezlerinde bazı lif özelliklerinin kalıtımı
}

\section{The inheritance of some fiber properties of cotton (Gossypium hirsutum L.) genotypes in line $x$ tester hybrids}

\author{
Nazife ÖZKAN ${ }^{1}$ iD, Osman ÇOPUR ${ }^{2 *}$ iD \\ ${ }^{1}$ Nazilli Pamuk Araştırma Enstitüsü Müdürlüğü, Aydın \\ ${ }^{2}$ Harran Üniversitesi Ziraat Fakültesi Tarla Bitkileri Bölümü, Şanlıurfa/TÜRKiYE
}

\section{To cite this article:}

Özkan, N., Çopur, O., 2018.

Pamuk (Gossypium

hirsutum L.) genotiplerinin çoklu dizi (line $x$ tester) melezlerinde bazı lif özelliklerinin kalıtımı. Harran Tarim ve Gida Bilimleri Dergisi, 22(2): 236247

\section{Address for Correspondence: Osman ÇOPUR e-mail: \\ ocopur@harran.edu.tr}

Received Date:

02.10.2017

Accepted Date:

08.02.2018

\section{Öz}

$\mathrm{Bu}$ araştırma, lif özellikleri ve adaptasyon kabiliyetleri farklı pamuk genotiplerinin, çoklu dizi (Line $x$ Tester) analiz yöntemine uygun oluşturulan $F_{1}$ popülâsyonlarında, incelenen özellikler yönünden genetik yapıуı incelemek, $F_{1}$ melez gücünü saptamak, uygun anaç ve melez kombinasyonları belirlemek amacıyla 2015 ve 2016 yıllarında Nazilli Pamuk Araştırma Enstitüsü'nde yürütülmüştür.

Amaca uygun olarak belirlenen 4 ana (Stoneville 468, Flash, GLORIA, TMN199) ve 7 baba (UA48, ZN1018, ADN712, GW2357, IPEK607, TMD139, TMN170 ) ebeveynin 2015 yılında melezlenmesiyle geliştirilen 28 adet melez kombinasyonu, ebeveynleri ile birlikte 2016 yılında 3 tekerrürlü olarak yetiştirilmiş ve genotiplere (ebeveynler ve melezler) ait lif özellikleri incelenmiştir.

Çalışma sonucunda; $1 \times 8,2 \times 8,4 \times 5$ ve $4 \times 9 F_{1}$ melezleri lif kopma uzaması, $3 \times 7,3 \times 10,1 \times 10$ ve $1 \times 7 F_{1}$ melezleri kısa lif içeriği, $2 \times 7$ ve $2 \times 10 F_{1}$ melezleri ise lif yeknesaklık oranı yönünden önemli bulunmuştur.

Ayrıca, ebeveynlerden Stoneville 468, TMD139 ve TMN170 genotipleri lif kopma uzaması, IPEK607 ve UA48 genotipleri kısa lif içeriği, GLORIA, IPEK607 ve UA48 genotipleri ise lif yeknesaklık oranı yönünden önemli bulunurken, incelenen lif özelliklerinin eklemeli olmayan gen/ler etkisiyle yönetildiği saptanmıştır.

Anahtar Kelimeler: Pamuk, Çoklu x Dizi, Heterosis, Lif kalitesi

\section{ABSTRACT}

This research was conducted to determine some superior fiber quality cotton genotypes, high yield, ginning percentage, high adaptation capacity characteristics which are constructed in (line $x$ tester) analysis in $F_{1}$, in terms of the characteristic researched, to examine the genetic structure, detect $F_{1}$ hybrid power; to identify suitable parents (line $x$ tester) and hybrid population at Nazilli Cotton Research Institute in between 2015 and 2016. 4 lines (Stonoville-468, FLASH, GLORIA, TMN199), 7 testers (GW2357, TMD139, TMN177, TMN170, IPEK607, ZN1018, UA48, ADN712) determined according to our aim were crossbred in 2015 and 28 hybrid combinations were obtained. This research was set up with three replicates and necessary observations were taken in 2015 and 2016. In terms of elongation, $1 \times 8,2 \times 8,4 \times 5$ and $4 \times 9 F_{1}$ hybrids, in terms of short fiber index, $3 \times 7,3 \times 10,1 \times 10$ and $1 \times 7 F_{1}$ hybrids, in terms of uniformity $2 \times 7$ and $2 \times 10 F_{1}$ hybrids were determined as most promising hybrid populations. The most promising line and tester; in terms of elongation STV-468, TMD139, TMN170, in terms of short fiber index, GLORIA, IPEK607, UA48, interms of uniformity GLORIA, IPEK607, UA48 were found important parents in terms of relevant characteristic. It was found out that the fiber properties examined are directed by the nonadditive genes.

Key Words: Cotton, Line x tester, Heterosis, Fiber quality 


\section{Giriş}

Pamuk, farklı kullanım alanlarıyla, hem ekonomik hem de sosyal açıdan önem arz eden önemli bir kültür bitkisidir. Öncelikle lifi için üretilen ve tohumdaki yağın yanı sıra protein, çiğit unu ve küspesi ile hem hayvan yemi hem de insan gıdası olarak önem arz eden pamuk bitkisi, ülke gereksinimini karşılamanın yanı sıra Türkiye ihracat gelirlerine \%18 oranında katkı vermektedir (Anonim, 2013). Dahası, pamuk tarımı Türkiye'nin sosyo-ekonomik yapısına çok önemli katkı vermektedir.

Uluslararası Pamuk İstişare Komitesi (ICAC)'nin verilerine göre, Avustralya, Türkiye, İsrail, Brezilya, Meksika 2015-2016 üretim sezonunda, birim alandan elde edilen verimde ilk beş sırayı alırken, ülkemiz, birim alandan elde edilen lif verimi bakımından dünyada ikinci sırada bulunmaktadır.

Pamuk ıslahında, yüksek verimin yanı sıra lif özellikleri üstün çeşitlerin geliştirilmesi de önemlidir. Bu nedenle, kopma anındaki lif uzama oranı ile lif yeknesaklık oranı yüksek, kısa lif içeriği ise düşük çeşitlerin geliştirilmesi tercih edilmektedir. Melezleme ıslahı, bu özelliklere sahip çeşitlerin ıslahında uygulanan yöntemlerdendir. Melezleme ıslahında uygun ebeveynlerin seçimi ise en önemli konudur. Ebeveyn seçiminde birçok yöntem kullanılmakla birlikte, bu konuda kullanılacak en önemli yöntemlerden biri çoklu dizi (line $\mathrm{x}$ tester) yöntemidir (Yıldırım ve İkiz, 1972; Falconer, 1981). Çoklu dizi analiz yöntemi, uygun ebeveyn ve melezlerin seçiminin yanı sıra kalıtımı zor olan kantitatif özellikleri kontrol eden gen etkilerini ve kalıtım derecelerini belirlemede önemli bir araçtır (Hallauer and Miranda, 1981, Goyal and Kumar, 1991, Başbağ ve ark. 2007). Bu yöntemle, $F_{1}$ generasyonunda uygun kombinasyonların belirlenmesi ve hem verimli hem de kaliteli çeşit geliştirme çalışmaları mümkün olmaktadır.

Çoklu Dizi (line $x$ tester) analiz yöntemi, erken kuşakta ümitvar melez popülasyonların belirlenmesini sağlarken, daha az, fakat daha ümitvar melez popülasyonlarla verimli ve kaliteli çeşit geliştirme çalışmalarını mümkün kılmaktadır. Araştırıcılar bu konuda, farklı lokasyonlarda çok sayıda çalışma yürütmüşlerdir. El-Feki ve ark., (1995), Amerika ve Rusya kökenli 6 adet pamuk hattı ( 2 baba 4 ana) ile yaptığı line $x$ tester çalışması sonucunda, incelenen tüm özellikler yönünden ticari heterosis gözlendiğini bildirirken, Zhu (1995), Gossypium hirsutum L. türü içindeki pamuk genotipleri ile oluşturulan melez popülasyonlarında; lif verimi ve lif kalitesi özellikleri yönünden olumlu heterosis saptandığı belirtilmiştir. Başal ve ark. (2009), beş ana ve üç babanın line $x$ tester yöntemiyle oluşturulan $15 F_{1}$ melezinde lif uzunluğu, lif dayanıklılığı, koza kütlü ağırlığı hariç tüm özelliklerde, eklemeli olmayan gen etkisi saptadıklarını bildirirken, Saravanan ve ark. (2010), 4 ana ve 3 baba ebeveyn ile line $x$ tester analiz yöntemi uyarınca oluşturdukları popülasyonda, lif uzunluğu, lif inceliği, lif mukavemeti ve üniformite özelliklerinin yönetiminde eklemeli olmayan genlerin etkin olduğunu bildirmişlerdir. Senthilkumar ve ark. (2010), 7 pamuk çeşidini ana ve 12 çeşidini baba olarak kullanarak oluşturdukları popülasyonda: kütlü verimi ve bazı lif kalite özelliklerinin yönetiminde eklemeli olmayan genlerin etkili olduğunu belirtmişlerdir. Boyacı (2011), türler arası melezleme ile oluşturulan popülasyonlarda; incelenen çoğu özelliğin yönetiminde, eklemeli olmayan gen etkilerinin önemli olduğunu bildirirken, kısa lif içeriği için negatif, lif yeknesaklık oranı ve diğer özellikler yönünden pozitif heterosis oluştuğunu saptamıştır. Güvercin (2016), Kahramanmaraş koşullarında; sekiz pamuk çeşidinin yanı sıra, on beş $F_{1}$ melez kombinasyonu, bitkisel materyal olarak kullanılmış ve lif verimi ile kalite özelliklerinin eklemeli olmayan gen etkileriyle yönetildiğini belirlemiştir.

Bu araştırma, lif kalite özellikleri ve adaptasyon kabiliyetleri farklı pamuk genotiplerden çoklu dizi (line $x$ tester) analiz yöntemine göre oluşturulan popülasyonlarda; incelenen özellikler yönünden, genetik yapıуı incelemek; $F_{1}$ melez gücünü saptamak ve uygun anaçlar ile melez 
kombinasyonları

belirlemek

amacıyla

yürütülmüştür.

\section{Materyal ve Metot}

\section{Araştırma yeri ve özellikleri}

Bu çalışma; 2015-2016 yıllarında, Nazilli Pamuk Araştırma Enstitüsü Deneme alanında yürütülmüştür. Deneme alanının azot içeriği orta düzeyde, fosfor ve potasyum seviyesi çok iyi, organik madde oranı düşük, $\mathrm{pH}$ seviyesi orta alkali, tuz içeriği düşük ve çok kireçli olduğu saptanmıştır. İklim özellikleri yönünden ise, temmuz ve ağustos aylarına ait ortalama maksimum sıcaklıkların $38.5{ }^{\circ} \mathrm{C}$ ve $38.2{ }^{\circ} \mathrm{C}$, minimum sıcaklıkların $29.1{ }^{\circ} \mathrm{C}$ ve $30.5^{\circ} \mathrm{C}$, ortalama sıcaklıkların $29.1{ }^{\circ} \mathrm{C}$ ve $30.5{ }^{\circ} \mathrm{C}$, ortalama nisbi nemin ise \%41.8 ve \% 51.6 olduğu saptanmıştır (Anonim, 2017). Pamuk tarımı dünyanın 37 kuzey ve 32 güney enlemleri arasında yapılmaktadır. Bu enlemler arasında yer alan bölgemizde nisan ve mayıs ayları yağışlı geçmekte ve bu nedenle ekimler gecikmekte ve hatta birkaç kez yenilenebilmektedir. Bazı yıllarda ise sonbahar ilk yağışları erken gelmekte, pamuk hasadında sorunlar ile karşılaşılabilmektedir.

\section{Bitkisel materyal ve kültürel uygulamalar}

Araştırmanın bitkisel materyalini, verim ve lif özellikleri üstün 4 ana ebeveynin (Stoneville 468, GLORIA, TMN199, FLASH) yanı sıra, baba ebeveyn olarak kullanılan 7 pamuk hat/çeşidi (UA48, ZN1018, ADN712, GW2357, IPEK607, TMD 139, TMN170) ile bu çeşitlerin çoklu dizi analiz yöntemine uygun melezlenmesiyle geliştirilen, 28 adet $F_{1}$ melez kombinasyonu oluşturmuştur. Melezlemede kullanılan ebeveynlere ait tohumlar 2012 ve 2013 yıllarında yapılan kendileme ile elde edilmiştir.

2015 yılında yapılan melezlemeleri takiben, elde edilen $F_{1}$ melez kombinasyonları ile ebeveynler (anaçlar), 2016 yılında, tesadüf blokları deneme desenine göre üç tekerrürlü yetiştirilmiştir. Genotipler, (ebeveynler ve melezler) tekerrürlerdeki her parsele $12 \mathrm{~m}$ uzunluğunda birer sıra, sıra arası $70 \mathrm{~cm}$ ve sıra üzeri $20 \mathrm{~cm}$ olacak şekilde 11 Mayıs 2016 tarihinde ekilmiştir.

Yetiştirme süresi boyunca, bir defa el ile üç defa da traktör ile makine çapası yapılmıştır. Ekimle birlikte $6 \mathrm{~kg} \mathrm{da}^{-1}$ saf azot (N) ile $6 \mathrm{~kg} \mathrm{da}^{-1}$ saf fosforun $\left(\mathrm{P}_{2} \mathrm{O}_{5}\right)$ 20-20-0 kompoze formunda verildiği parsellere, birinci sudan önce (29 Haziran 2016) $9 \mathrm{~kg} \mathrm{da}^{-1}$ saf azot (N) üre formunda uygulanmıştır. Sezon boyunca 4 defa sulama yapılan çalışmada, ayrıca, Thrips (Thrips tabaci) ve Empoaska (Empoasca spp.)'ya karşı $35 \mathrm{~g} \mathrm{da}^{-1}$ dozunda Acetamiprid, Kırmızı örümceğe karşı $50 \mathrm{~g}$ $\mathrm{da}^{-1}$ Abamectin ve Yaprak bitine karşı ise $100 \mathrm{cc}$ $\mathrm{da}^{-1}$ Dimethoate kullanılmıştır. Birinci el hasat, 28 Eylül 2016 ve ikinci el hasat ise, 20 Ekim 2016 olmak üzere iki defada tamamlanmıştır.

\section{Verilerin değerlendirilmesi}

Çalışmada, her özellik için parsel ortalamasına göre saptanan veriler, çoklu dizi (line $\mathrm{x}$ tester) yöntemine göre (Kempthorne, 1957), TARPOPGEN istatistik paket programı (Özcan ve Açıkgöz,1999) yardımıyla yapılmıştır.

Çalışmada, incelenen özelliklerin genel ve özel uyuşma yetenekleri varyanslarının saptanması yanında, seleksiyon zamanının belirlenmesi için oldukça önemli olan, Genel Uyuşma Yeteneği (GUY) varyansının Özel Uyuşma Yeteneği (ÖUY) varyansına oranı da belirlenmiştir. Matzinger (1963)'e göre; genel uyuşma yeteneği eklemeli ve eklemeli $x$ eklemeli epistatik gen etkisini, özel uyuşma yeteneği ise dominant ve tüm epistatik gen etkilerini içermektedir. Bu durum, genel uyuşma yeteneği varyansının, özel uyuşma yeteneği varyansına oranı eklemeli ve dominant gen etkilerini tahminlemeye yardımcı olmaktadır. Matzinger (1963)'e göre özelliklerin yönetiminde etkin olan gen etkileri aşağıdaki gibidir;

$\left(\sigma_{\text {(GUY) }}^{2} / \sigma_{(\text {ÖUY })}^{2}\right)>1=$ Eklemeli gen etkileri (1) $\left(\sigma^{2}\right.$ (GUY) $/ \sigma^{2}$ (öUY) $)>-1=$ Eklemeli $x \quad$ Eklemeli, Epistatik gen etkileri

$\left(\sigma^{2}\right.$ (GUY) $/ \sigma^{2}$ (ÖUY) $)<1=$ Dominant gen etkileri

$\left(\sigma^{2}\right.$ (GUY) $/ \sigma^{2}$ (ÖUY) $)<-1=$ Eklemeli $x$ Dominant gen etkileri, Dominant $x$ Dominant Epistatik gen etkileri 
Genel uyuşma yeteneği varyansının, özel uyuşma yeteneği varyansına oranı; ( $\sigma^{2}{ }_{(\mathrm{GUY})}$ $/ \sigma^{2}$ (öuY) $) \pm 1^{\prime}$ den büyük olduğu durumlarda, anılan özelliklerin eklemeli genler tarafından yönetildikleri söylenebilir. $\mathrm{Bu}$ özellikler için yapılacak seleksiyonlarda tek bitki seçimine $F_{2}$ generasyonunda başlanmalıdır.

Genel uyuşma yeteneği varyansının, özel uyuşma yeteneği varyansına oranı; ( $\sigma^{2}$ (GUY) $/ \sigma 2$ (öuy) 1'den küçük bulunan özelliklerin, eklemeli olmayan gen etkileri tarafından yönetildikleri söylenebilir (Matzinger, 1963). Bu nedenle, anılan özellikler için tek bitki seleksiyonlarının, $F_{4}-F_{5}$ generasyonlarında yapılması daha uygun olacaktır.

\section{Melez azmanlığı (Heterosis) (\%)}

Melez azmanlığı, incelenen özellikler yönünden aşağıda verilen eşitliğe göre hesaplanmıştır (Chiang ve Smith, 1967). Heterosisteki farkın ('F1 - ‘O) önemliliğini kontrol için $t$ testi kullanılmıştır.

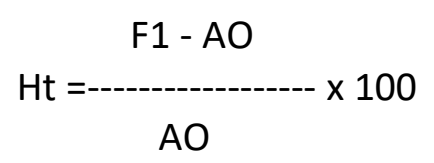

$\mathrm{Ht}$ : Heterosis

$\mathrm{F}_{1}: \mathrm{F}_{1}$ ortalaması

AO: Anaçlar ortalaması

Üstün melez azmanlığı (Heterobeltiosis) (\%)

Üstün melez azmanlığı, incelenen özellikler yönünden aşağıdaki formül uyarınca hesaplanmıştır (Fonseca ve Patterson, 1968).

$\mathrm{Hb}=\frac{F_{1}-\ddot{U} A}{\text { ÜA }}$

$\mathrm{Hb}$ : Heterobeltiosis

$F_{1}: F_{1}$ ortalaması

ÜA: Üstün anaç ortalaması

Heterobeltiosis değerlerindeki farkın karşılaştırılmasında ise, ön varyans analizindeki melezlere ilişkin, \%1 ve \%5 önem seviyelerinin belirlendiği LSD değerleri kullanılmıştır.

$\mathrm{Bu}$ çalışmada kullanılan ebeveynlerin ve melezlerin $\left(F_{1}\right)$ incelenen özelliklerine ait veriler, JMP 7.0.1 istatistik paket programında, tesadüf blokları deneme desenine göre varyans analizine tabi tutulmuş ve ortalamalar LSD testine göre gruplandırılmıştır.

\section{Araştırma Bulguları ve Tartışma}

\section{Kopma anındaki lif Uzama oranı}

Genotiplere ait kopma anındaki lif uzama oranı \%7.1 (5×5) ile \%5.1 (4x7) arasında değişirken (Çizelge 3), bu varyasyonun önemli olduğu (Çizelge 1) saptanmıştır. Anılan Özellik yönünden anaçlara karşı, melezlerin üstün olmamakla birlikte, hem ebeveynler arası hem de, melezler arası faklılığın önemli olduğu ve genotipler arası farklılığa en yüksek katkıyı babaların verdiği Çizelge 4'ten izlenmektedir.

Çizelge 1'den, kopma anındaki lif uzama oranı yönünden, babaların ve anaların \%1 düzeyde önemli, ana baba interaksiyonunun ise, önemsiz olduğu tespit edilmiştir. Çalışmada, ebeveynlere ait genel uyum yeteneği varyansının (0.023), melezlere ait özel uyum yeteneği varyansına oranı sıfır (0) olarak tespit edilirken, kopma anındaki lif uzama oranı oluşumunda etkili olan genel uyum yeteneği varyansı içerisinde yer alan anaların etkisi \% 9.47, babaların etkisi \% 81.29 olarak tespit edilmiştir. Özel uyum yeteneği varyansı içerisinde yer alan analar $x$ babalar interaksiyonunun etkisi ise \% 9,24 olarak saptanmıştır.

Ebeveynlere ait GUY varyansının, melezlere ait ÖUY varyansına oranı ( ${ }^{2}$ GUY/ $\delta^{2}$ ÖUY), -1 ile 0 arasında olduğunda, anılan özelliğin yönetiminde eklemeli $x$ dominant gen etkileri ile, dominant $x$ dominant ve epistatik gen etkilerinin önemli olduğunu işaret etmektedir. Çalışmada eklemeli olmayan gen etkilerinin önemli olduğu saptanmış ve benzer bulgular, Karademir ve ark., (2009), Güvercin, (2016) ve Karademir ve Gencer, (2010) tarafından da belirlenmiştir. 
Özkan ve Çopur 2018. Harran Tarim ve Gida Bilimleri Dergisi, 22(2):236-247

Çizelge 1. Kopma anındaki lif uzama oranı (\%) değerlerine ilişkin çoklu dizi varyans analiz sonuçları Table 1. The result of analysis of variance related to elongation (\%) values

\begin{tabular}{|c|c|c|c|c|}
\hline $\begin{array}{l}\text { Varyasyon kaynakları } \\
\text { Variation Resources }\end{array}$ & $\begin{array}{l}\text { Serbestlik derecesi } \\
\text { Degree of freedom }\end{array}$ & $\begin{array}{l}\text { Kareler toplamı } \\
\text { Sum of squares }\end{array}$ & $\begin{array}{l}\text { Kareler ortalaması } \\
\text { Mean of squares }\end{array}$ & $\begin{array}{l}\text { F değeri } \\
\text { F values }\end{array}$ \\
\hline Tekerrürler (Replication) & 2 & 2.071 & 1.036 & $6.180 * *$ \\
\hline Genotipler (Genotypes) & 38 & 54.316 & 1.429 & $8.530 * *$ \\
\hline Ebeveynler (Parents) & 10 & 21.835 & 2.184 & $13.030 * *$ \\
\hline $\begin{array}{l}\text { Anaçlara Karşı Melezler } \\
\text { Parent Vs Hybrids }\end{array}$ & 1 & 0.130 & 0.130 & $0.775 \mathrm{~ns}$ \\
\hline Melezler (Hybrids) & 27 & 32.351 & 1.198 & $7.150 * *$ \\
\hline Analar (Lines) (L) & 3 & 3.064 & 1.021 & $6.095^{* *}$ \\
\hline Babalar (Tester) (T) & 6 & 26.298 & 4.383 & $26.156^{* *}$ \\
\hline Ana x Baba (LinexTester) & 18 & 2.990 & 0.166 & $0.991 \mathrm{~ns}$ \\
\hline $\begin{array}{l}\text { Hata } \\
\text { Error }\end{array}$ & 76 & 12.735 & 0.168 & \\
\hline Toplam (Total) & 116 & 69.123 & & \\
\hline $\begin{array}{l}\sigma^{2} \text { G.UY } \\
\sigma^{2} \text { Ö.U.Y } \\
\sigma^{2} \text { G.UY/ } / \sigma^{2} \text { Ö.U.Y }\end{array}$ & $\begin{array}{l}0.023 \\
0.000 \\
0.000 \\
\end{array}$ & & $\begin{array}{l}\text { Anaların etkisi (\%) } \\
\text { Babaların etkisi(\%) } \\
\text { AnalarxBabalar(\%) }\end{array}$ & $\begin{array}{l}9.470 \text { (Lines) } \\
81.289 \text { (Tester) } \\
9.241 \text { (LXT) } \\
\end{array}$ \\
\hline
\end{tabular}

ns: no significant, ${ }^{* *}: \mathrm{p} \leq 0.01$

Çizelge 2. Kopma anındaki lif uzama oranı (\%) bakımından anaçların genel ortalama değerleri, oluşan gruplar ve saptanan genel uyum yeteneği değerleri (GUY)

Table 2. Values of general combining ability (GCA) formed groups, general average values of the parents in terms of elongation

\begin{tabular}{|c|c|c|c|}
\hline $\begin{array}{c}\text { Genotip } \\
\text { No }\end{array}$ & $\begin{array}{l}\text { Ebeveynler } \\
\text { Parents }\end{array}$ & $\begin{array}{c}\text { Kopma anındaki lif uzama } \\
\text { oranı ( \%) }\end{array}$ & $\begin{array}{l}\text { GUY Etkileri } \\
\text { GCA Effects }\end{array}$ \\
\hline \multirow{2}{*}{$\begin{array}{l}\text { Genotypes } \\
\text { number }\end{array}$} & \multicolumn{3}{|c|}{ Elongation ratio } \\
\hline & \multicolumn{3}{|c|}{ Analar (Lines) } \\
\hline 1 & TMN199 & $5.5 \mathrm{e}$ & $-0.262 * *$ \\
\hline 2 & FLASH & $6.2 \mathrm{~d}$ & $0.105^{* *}$ \\
\hline 3 & GLORIA & $5.6 \mathrm{e}$ & $-0.086 n s$ \\
\hline \multirow[t]{2}{*}{4} & STV-468 & $6.4 c-d$ & $0.243 * *$ \\
\hline & \multicolumn{3}{|c|}{ Babalar (Tester) } \\
\hline 5 & ADN712 & $6.9 b-c$ & $0.354^{* *}$ \\
\hline 6 & GW2357 & $5.4 \mathrm{e}$ & $-0.496 * *$ \\
\hline 7 & IPEK607 & $5.5 \mathrm{e}$ & $-0.696 * *$ \\
\hline 8 & TMD139 & $7.7 \mathrm{a}$ & $0.895^{* *}$ \\
\hline 9 & TMN170 & $7.1 \mathrm{~b}$ & $0.529 * *$ \\
\hline 10 & UA48 & $5.0 \mathrm{e}$ & $-0.496 * *$ \\
\hline 11 & ZN1018 & $6.6 \mathrm{~b}-\mathrm{d}$ & $-0.088 n s$ \\
\hline Ortalama (Means) & \multicolumn{3}{|c|}{6.1} \\
\hline CV (\%) & \multicolumn{3}{|c|}{5.4} \\
\hline LSD $(0.05)_{\text {Genotipler }}$ & \multicolumn{3}{|c|}{0.54} \\
\hline
\end{tabular}

ns: no significant, ${ }^{* *}: p \leq 0.01$

Çizelge 2'den, anaçların kopma anındaki lif uzama oranı, \% 5.0 (UA48) ile \% 7.7 (TMD139) arasında değiştiği ve ana ebeveynlerde genel uyum yeteneği STV-468 $\left(0.243^{* *}\right)$ çeşidinde pozitif yönde önemli bulunmuştur. Analardan, TMN199 $\left(-0.262^{* *}\right)$ ve GLORIA $(-0.086)$ negatif yönde önemli bulunmuştur. En uygun baba ebeveyn ve genel uyum yeteneği en yüksek TMD139 (0.895) genotipinde ve pozitif yönden önemli, GW2357 $\left(-0.496^{* *}\right)$, UA48 $\left(0.496^{* *}\right)$ ve
IPEK607 $\left(-0.696^{* *}\right)$ çeşitlerinde (baba) ise negatif yönden önemli bulunmuştur.

Çizelge 3'den, melezlerin kopma anındaki lif uzama oranı değerleri, en yüksek \% $7.1(4 \times 5)$ ve en düşük ise $\% 5.1$ (3x7) olarak saptanmıştır. Anaçların ortalaması ile eşit değerdedir. Aynı çizelgeden, melezlerin hiç birinde önemli oranda melez azmanlığı tespit edilmemiştir. Aynı özellik yönünden heterobeltiosis değerlerini incelediğimiz zaman, $1 \times 5$, $1 \times 8,1 \times 11,2 \times 5,2 \times 8,3 \times 8$ ve $4 \times 8$ melezlerinde kopma 
Özkan ve Çopur 2018. Harran Tarim ve Gida Bilimleri Dergisi, 22(2):236-247

anındaki lif uzama oranı yönünden heterobeltiosis görülmektedir. Bu melez kombinasyonlar, bu özellik değerlerinin negatif yönde önemli olduğu yönünden uygun bulunmamıştır.

Çizelge 3. Kopma anındaki lif uzama oranı yönünden melezlerin ortalama değerleri, oluşan gruplar heterosis (\%) (Ht), heterobeltiosis (\%) $(\mathrm{Hb})$ ve özel uyum yeteneği (ÖUY)

Table 3. Average values of hybrids in terms of elongation, formed groups, heterosis (\%) (Ht), heterobeltiosis (\%) (Hb) and special combining ability (SCA)

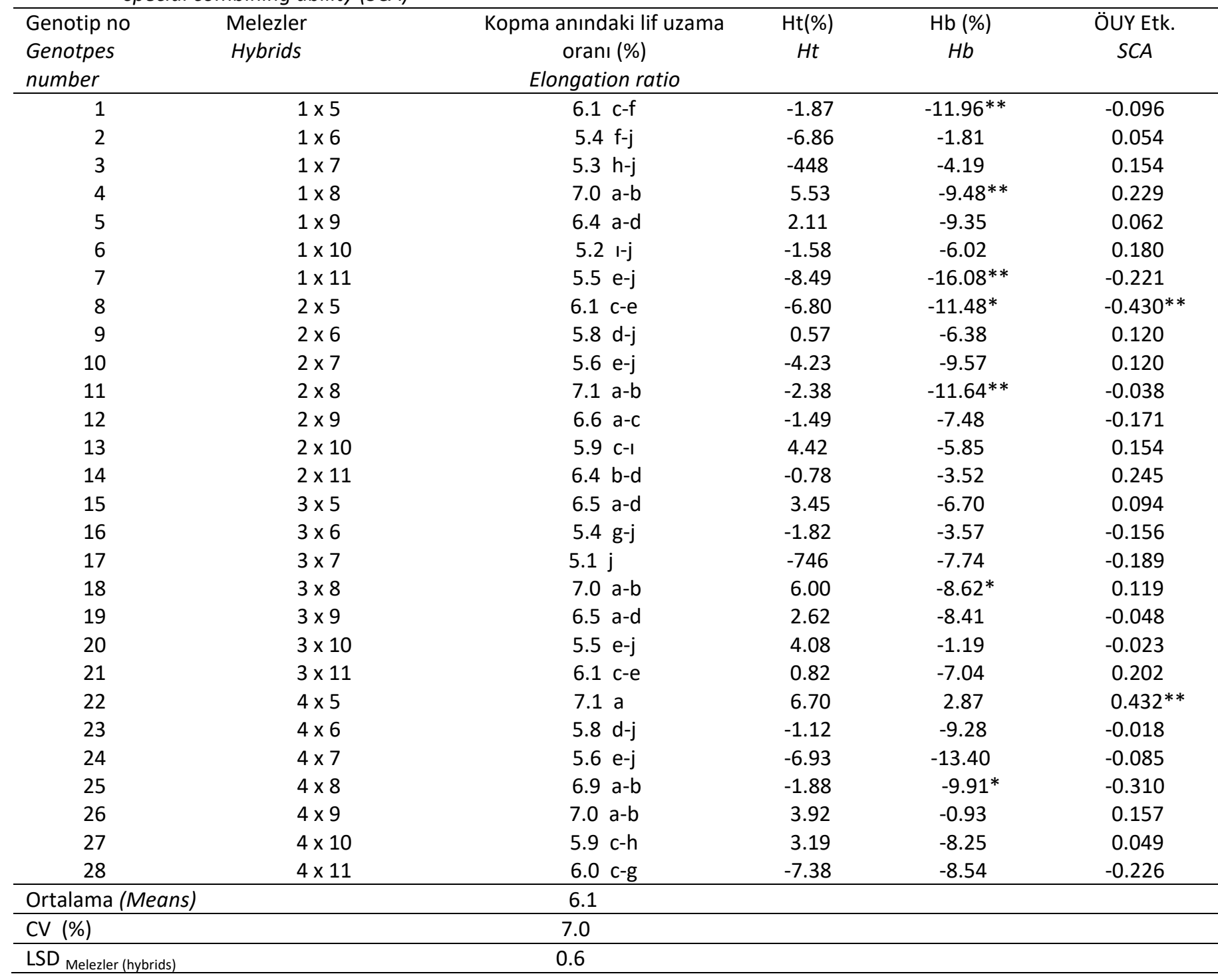

Çizelge 3'den, özel uyum yetenekleri yönünden en iyi uyum değerinin, $4 \times 5(0.432 * *)$ melezinde ve pozitif yönde önemli olduğu; $2 \times 5 \quad(-0.430 * *)$ melezinde ise negatif yönde önemli olduğu izlenebilmektedir.

\section{Kısa lif içeriği (\%)}

Çizelge 4'den, kısa lif içeriği (KLi) yönünden, babaların ve anaların (\% 0.01) önemli olduğu belirlenirken, ana baba interaksiyonu önemsiz bulunmuştur. Çalışmada ebeveynlere ait genel uyum yeteneği varyansının 0.108; melezlere ait özel uyum yeteneği varyansının 0.143 olduğu; genel uyum yeteneği varyansının özel uyum yeteneği varyansına oranının ise 0.755 olduğu izlenebilmektedir. Kısa lif içeriği oluşumunda etkili olan genel uyum yeteneği varyansı içerisinde yer alan analar etkisi \% 9.57 ve babaların etkisi \% 81.46 olarak saptanmıştır. Ayrıca, özel uyum yeteneği varyansı içerisinde yer alan ana $x$ baba interaksiyonunun etkisi ise \% 8.96 olarak tespit edilmiştir. Aynı çizelgeden, ana ve babalar önemli, anaxbaba interaksiyonunu ise önemsiz bulunmuştur. 
Çizelge 4. Kısa lif içeriği (\%) değerlerine ilişkin çoklu dizi varyans analiz sonuçları Table 4. The result of analysis of variance related to short fiber index values

\begin{tabular}{|c|c|c|c|c|}
\hline $\begin{array}{l}\text { Varyasyon kaynakları } \\
\text { Variation resources }\end{array}$ & $\begin{array}{l}\text { Serbestlik derecesi } \\
\text { Degree of freedom }\end{array}$ & $\begin{array}{l}\text { Kareler toplamı } \\
\text { Sum of squares }\end{array}$ & $\begin{array}{l}\text { Kareler ortalaması } \\
\text { Mean of squares }\end{array}$ & $\begin{array}{l}\text { F değeri } \\
F \text { values }\end{array}$ \\
\hline Tekerrürler (Replications) & 2 & 1.702 & 0.851 & 3.452 \\
\hline Genotipler (Genotypes) & 38 & 64.189 & 1.689 & $6.851^{* *}$ \\
\hline Ebeveynler (Parents) & 10 & 24.156 & 2.416 & $9.797 * *$ \\
\hline $\begin{array}{l}\text { Anaçlar Karşı Melezler } \\
\text { Parent Vs Hybrids }\end{array}$ & 1 & 0.583 & 0.583 & $2.363 \mathrm{~ns}$ \\
\hline $\begin{array}{l}\text { Melezler } \\
\text { Hybrids }\end{array}$ & 27 & 39.451 & 1.461 & $5.926 * *$ \\
\hline $\begin{array}{l}\text { Analar } \\
\text { Lines }\end{array}$ & 3 & 3.777 & 1.259 & $5.106 * *$ \\
\hline $\begin{array}{l}\text { Babalar } \\
\text { Tester }\end{array}$ & 6 & 32.138 & 5.356 & $21.725 * *$ \\
\hline $\begin{array}{l}\text { Ana } x \text { baba } \\
\text { Line } \times \text { Tester }\end{array}$ & 18 & 3.536 & 0.196 & $0.797 \mathrm{~ns}$ \\
\hline $\begin{array}{l}\text { Hata } \\
\text { Error }\end{array}$ & 76 & 18.738 & 0.247 & \\
\hline $\begin{array}{l}\text { Toplam } \\
\text { Total }\end{array}$ & 116 & 84.629 & & \\
\hline $\begin{array}{l}\sigma 2 \text { G.UY } \\
\sigma 2 \text { Ö.U.Y } \\
\sigma 2 G . U Y / \sigma 2 \text { Ö.U.Y }\end{array}$ & $\begin{array}{l}0.108 \\
0.143 \\
0.755\end{array}$ & & $\begin{array}{l}\text { Anaların etkisi (\%): } \\
\text { Babaların etkisi(\%): } \\
\text { Analar*Babalar(\%): }\end{array}$ & $\begin{array}{l}\text { 9,573 (Lines) } \\
\text { 81,464 (Tester) } \\
8,963 \text { (LxT) }\end{array}$ \\
\hline
\end{tabular}

ns: no significant, ${ }^{* *}: \mathrm{p} \leq 0.01$

Ebeveynlere ait GUY varyansının, melezlere ait ÖUY varyansına oranının ( $ð^{2}$ GUY/ $ð^{2}$ ÖUY 0.75) 1 ile 0 arasında bir değer olması, bu özelliğin kalıtımında dominant gen etkilerinin önemli olduğunu göstermektedir. Bu özelliğin, kalıtımında eklemeli olmayan gen etkilerinin önemli olduğu, Ünay, (1993), Lukonge ve ark., (2007), Başal ve ark., (2009), Senthilkumar ve ark., (2010), Saravanan ve ark., (2010) ve Güvercin, 2016) tarafından da bildirilmektedir.

Çizelge 5. Kısa lif içeriği (\%KLi) bakımından anaçların ortalama değerleri, oluşan gruplar ve saptanan genel uyum yeteneği Table 5. Values of general combining ability (GCA) formed groups, average values of the parents in terms of short fiber index

\begin{tabular}{|c|c|c|c|}
\hline $\begin{array}{l}\text { Genotip no } \\
\text { Genotypes number }\end{array}$ & $\begin{array}{c}\text { Ebeveynler } \\
\text { Parents }\end{array}$ & $\begin{array}{l}\text { Kısa lif içeriği (\%) } \\
\text { Short fiber content }\end{array}$ & $\begin{array}{c}\text { GUY Etkileri } \\
\text { GCA }\end{array}$ \\
\hline & \multicolumn{3}{|c|}{ Analar (Lines) } \\
\hline 1 & TMN199 & $5.2 \mathrm{c}-\mathrm{d}$ & $0.327^{* *}$ \\
\hline 2 & FLASH & $5.9 a-b$ & $-0.101 n s$ \\
\hline 3 & GLORIA & $4.5 \mathrm{e}$ & $-0.249 * *$ \\
\hline \multirow[t]{2}{*}{4} & STV 468 & $5.6 \mathrm{~b}-\mathrm{c}$ & $0.023 n s$ \\
\hline & \multicolumn{3}{|c|}{ Babalar (Tester) } \\
\hline 5 & AND712 & $5.6 \mathrm{~b}-\mathrm{c}$ & $0.383^{* *}$ \\
\hline 6 & GW2357 & $6.3 \mathrm{a}$ & $0.683^{* *}$ \\
\hline 7 & IPEK607 & $3.5 \mathrm{f}$ & $-1.058 * *$ \\
\hline 8 & TMD139 & $5.0 \mathrm{~d}$ & $0.150 * *$ \\
\hline 9 & TMN170 & $5.2 \mathrm{c}-\mathrm{d}$ & 0.075 \\
\hline 10 & UA48 & $3.6 \mathrm{f}$ & $-0.783^{* *}$ \\
\hline 11 & ZN1018 & $5.1 \mathrm{~d}$ & $0.550 \mathrm{~ns}$ \\
\hline Ortalamalar (Means) & & 5.1 & \\
\hline CV (\%) & & 6.02 & \\
\hline LSD $(0.5)_{\text {Genotipler (genotypes) }}$ & & 0.52 & \\
\hline
\end{tabular}

ns: no significant, ${ }^{* *}: p \leq 0.01$

Çizelge 5'den, anaçların kısa lif içeriği, \%3.5 ile \%6.3 arasında değişmektedir. Ana ebeveynlerden en yüksek kısa lif içeriğinin FLASH çeşidinden, en düşük kısa lif içeriğinin ise GLORIA çeşidinden elde 
edildiği görülebilmektedir. Baba ebeveynlerden en yüksek kısa lif içeriği, GW2357 hattında, en düşük kısa lif içeriği ise iPEK607 çeşidinde saptanmıştır. Aynı çizelgeden, kısa lif içeriği yönünden anaçlara ilişkin genel uyum yeteneği etkileri, GLORIA çeşidinde negatif yönde önemli; GW2357 hattında ise pozitif yönde önemli bulunmuştur. Kısa lif içeriği yönünden çeşit ıslahında GLORIA ve IPEK607 çeşitlerinin uygun ebeveynler olabileceği kanaatine varılmıştır.

Çizelge 6. Kısa lif içeriği yönünden, melezlerin ortalama değerleri, oluşan gruplar heterosis (\%) (Ht), heterobeltiosis ( \%) (Hb) ve özel uyum yeteneği (ÖUY)

Table 6. Average values of hybrids in terms of short fiber index, formed groups, heterosis (\%) (Ht), heterobeltiosis (\%) (Hb) and special combining ability (SCA)

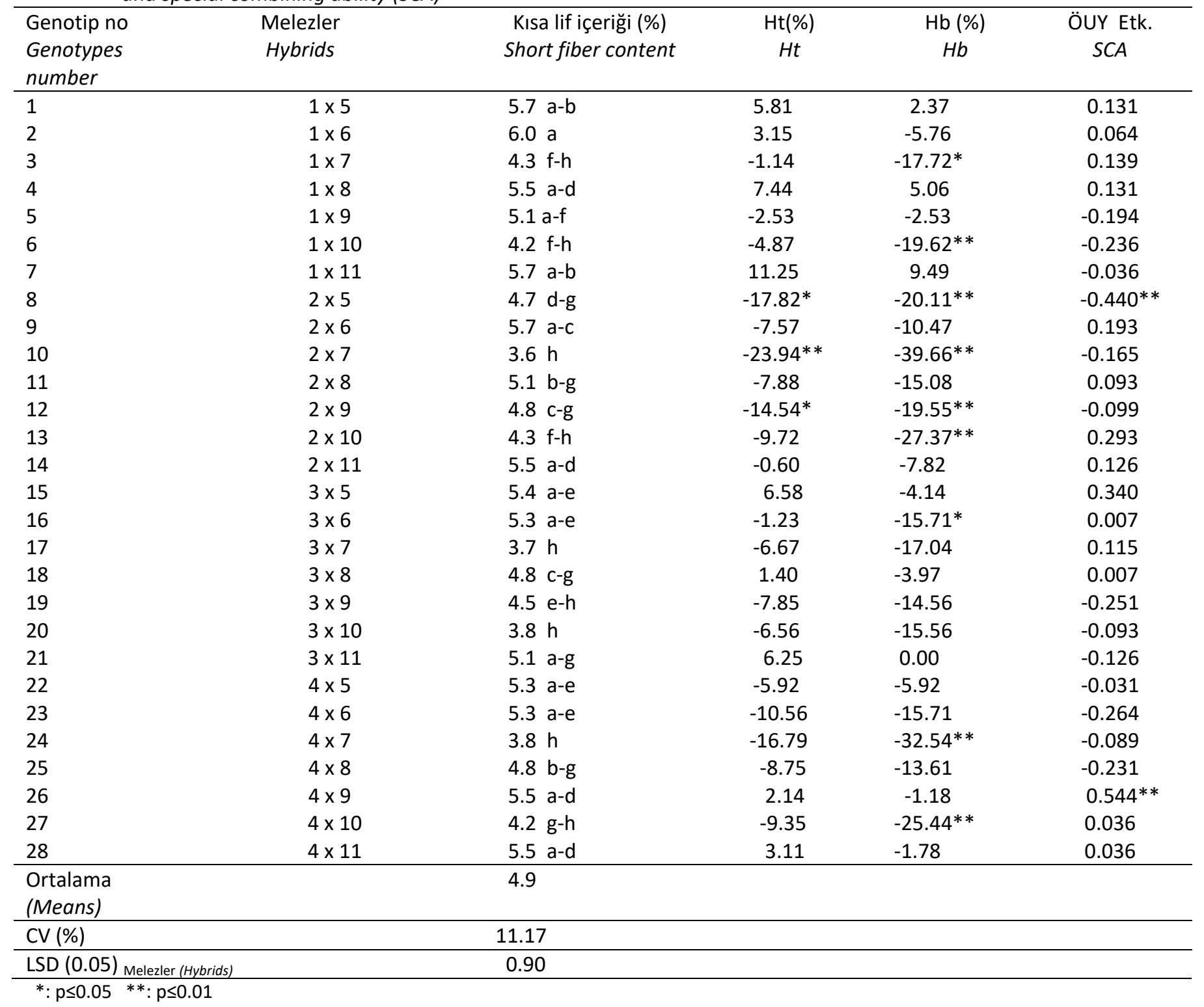

Çizelge 6'dan, en yüksek kısa lif içeriği $1 \times 6$ melezinde, en düşük kısa lif içeriği ise $3 \times 7$ ve $2 \times 7$ melezlerinde saptanmıştır. Melezlerde anaçların ortalamasından daha düşük kısa lif içeriği değerlerine ulaşılmıştır.

Aynı çizelgeden, melezlerin bazılarında melez azmanlığı tespit edilmiş olmakla birlikte, heterosisin çoğu kombinasyonlarda negatif yönde önemli olduğu saptanmıştır.

Çizelge 6'dan, 2X7, $2 \times 5$ ve $2 \times 9$ kombinasyonlarında oluşan kısa lif içeriği heterosis değerinin negatif yönde önemli olduğu görülmektedir.

Aynı özellik yönünden heterobeltiosis değerlerinin de negatif yönde olduğu görülmektedir. $1 \times 7,2 \times 5,2 \times 7,2 \times 10$ ve $4 \times 7$ melezleri düşük kısa lif içeriği açısından uygun ebeveynler olarak seçilebilir. Benzer bulgular ElFeki ve ark., (1995), Zhu, (1995) ve Boyacı, (2011) tarafından da saptanmıştır. 
Çizelge 8. Lif yeknesaklık oranı değerlerine ilişkin çoklu dizi varyans analiz sonuçları Table 8. The result of analysis of variance related to uniformity index values

\begin{tabular}{|c|c|c|c|c|}
\hline $\begin{array}{l}\text { Varyasyon kaynakları } \\
\text { Variation resources }\end{array}$ & $\begin{array}{l}\text { Serbestlik derecesi } \\
\text { Degree of freedom }\end{array}$ & $\begin{array}{l}\text { Kareler } \\
\text { toplamı } \\
\text { Sum of } \\
\text { squares }\end{array}$ & $\begin{array}{l}\text { Kareler ortalaması } \\
\text { Mean of squares }\end{array}$ & $\begin{array}{l}\text { F değeri } \\
F \text { values }\end{array}$ \\
\hline Tekerrürler & 2 & 1.147 & 0.573 & 1.056 \\
\hline Replications & & & & \\
\hline $\begin{array}{l}\text { Genotipler } \\
\text { Genotypes }\end{array}$ & 38 & 60.845 & 1.601 & $2.949 * *$ \\
\hline $\begin{array}{l}\text { Ebeveynler } \\
\text { Parents }\end{array}$ & 10 & 13.196 & 1.320 & $2.431 \mathrm{~ns}$ \\
\hline $\begin{array}{l}\text { Anaçlara karşı melezler } \\
\text { Parent Vs Hybrids }\end{array}$ & 1 & 0.571 & 0.571 & $1.053 \mathrm{~ns}$ \\
\hline $\begin{array}{l}\text { Melezler } \\
\text { Hybrids }\end{array}$ & 27 & 47.078 & 1.744 & $3.212 * *$ \\
\hline $\begin{array}{l}\text { Analar } \\
\text { Lines (L) }\end{array}$ & 3 & 2.437 & 0.812 & $1.496 \mathrm{~ns}$ \\
\hline $\begin{array}{l}\text { Babalar } \\
\operatorname{Tester}(T)\end{array}$ & 6 & 23.063 & 3.844 & $7.080 * *$ \\
\hline $\begin{array}{l}\text { Ana x baba } \\
\text { LineXTester } \\
\text { Hata }\end{array}$ & 18 & 21.578 & 1.199 & $2.208^{* *}$ \\
\hline Error & 76 & 41.260 & 0.543 & \\
\hline Toplam (Total) & 116 & 103.252 & & \\
\hline$\sigma 2 \mathrm{GUY}$ & 0.012 & & Anaların etkisi \% & 5.176 (Lines) \\
\hline б2 ÖUY & 0.219 & & Babaların etkisi \% & 48.990 (Tester) \\
\hline 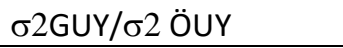 & 0.05 & & AnalarxBabalar \% & $45.834(L x T)$ \\
\hline
\end{tabular}

ns: no significant, ${ }^{* *}: \mathrm{P} \leq 0.01$

Çizelge 9. Lif yeknesaklık oranı bakımından anaçların genel ortalama değerleri, oluşan gruplar ve saptanan genel uyum yeteneği (guy)

Table 9. Values of general combining ability (GCA) formed groups, general average values of the parents in terms of uniformity index

\begin{tabular}{lccc}
\hline $\begin{array}{l}\text { Genotip no } \\
\text { Genotypes number }\end{array}$ & $\begin{array}{c}\text { Anaçlar } \\
\text { Parents }\end{array}$ & $\begin{array}{c}\text { Lif yeknesaklık oranı (\%) } \\
\text { Fiber uniformity index }\end{array}$ & $\begin{array}{c}\text { GUY Etkileri } \\
\text { GCA Effects }\end{array}$ \\
\hline 1 & Analar (Lines) & $-0.258^{* *}$ \\
2 & TMN199 & 85.6 b-c & $0.180^{* *}$ \\
3 & FLASH & $85.2 \mathrm{c}$ & $-0.044 \mathrm{~ns}$ \\
4 & GLORIA & $85.8 \mathrm{~b}-\mathrm{c}$ & $0.123 \mathrm{~ns}$ \\
\hline & STV468 & $85.4 \mathrm{c}$ & $-0.267^{* *}$ \\
\hline 5 & & Babalar (Tester) & $-0.667^{* *}$ \\
6 & AND712 & $85.2 \mathrm{c}$ & $0.692^{* *}$ \\
7 & GW2357 & $85.0 \mathrm{c}$ & $-0.192 \mathrm{~ns}$ \\
8 & iPEK607 & $86.6 \mathrm{a}-\mathrm{b}$ & $0.042 \mathrm{~ns}$ \\
9 & TMD139 & $85.9 \mathrm{~b}-\mathrm{c}$ & $0.833^{* *}$ \\
10 & TMN170 & $85.6 \mathrm{~b}-\mathrm{c}$ & $-0.442^{* *}$ \\
11 & UA48 & $87.2 \mathrm{a}$ & \\
\hline Ortalama (Means) & ZN1018 & $85.4 \mathrm{c}$ & 85.72 \\
\hline CV (\%) & & 0.7 & \\
\hline LSD & & 1.05 & \\
(Genotypes) & & & \\
\hline
\end{tabular}

ns: no significant, $* *$ : $\mathrm{P} \leq 0.01$

Çizelge 6'dan, özel uyum yeteneklerinin; 4X9 melezinde pozitif yönde önemli olduğu ve $2 \times 5$ melezinde ise negatif yönde önemli olduğu görülmektedir.

\section{Lif yeknesaklık oranı}

Çizelge 7'den, lif yeknesaklık oranı yönünden, anaların önemsiz, baba ve anaxbaba interaksiyonunun \%1 düzeyde önemli olduğu tespit 
edilmiştir. Çalışmada, ebeveynlere ait genel uyum yeteneği varyansı 0.012 ve melezlere ait özel uyum yeteneği varyansı 0.219 olarak; genel uyum yeteneği varyansının, özel uyum yeteneği varyansına oranı ise 0.05 olarak saptanmıştır. Aynı çizelgeden, lif yeknesaklık oranı oluşumunda etkili olan genel uyum yeteneği varyansı içerisinde yer alan anaların etkisinin \% 5.18, babaların etkisinin \% 48.99 ve ana $x$ baba interaksiyonunun etkisi ise \% 45.83 olarak saptandığı izlenebilmektedir.

Lif yeknesaklı oranı yönünden ebeveynlere ait GUY varyansının melezlere ait ÖUY varyansına oranının ( $\delta^{2}$ GUY / $ð^{2}$ ÖUY) 0.05 olması, bu özelliğin kalıtımında eklemeli olmayan gen etkilerinin önemli olduğunu bildirmektedir. Bu özellik yönünden eklemeli olmayan gen etkilerinin önemli olduğuna dair benzer bulgular, Ünay, (1993), Başal ve ark., (2009), Saravanan ve ark. (2010), Senthilkumar ve ark., (2010), Boyacı, ( 2011) ve Güvercin, (2016) tarafından da saptanmıştır.

Çizelge 9'dan, anaçların lif yeknesaklık oranı değerleri, \% 87.2 ile \% 85.0 arasında değişkenlik göstermiştir. En yüksek lif yeknesaklık oranı değeri UA48 hattında görülürken, bu hattı IPEK607 çeşidinin izlediği, en düşük lif yeknesaklık oranı değerlerinin, FLASH, ADN712 ve GW2357 genotiplerinde saptandığı aynı çizelgeden izlenebilmektedir. Lif yeknesaklık oranı yönünden anaçlara ilişkin genel uyum yeteneği etkilerinin FLASH, IPEK607 ve UA48 genotiplerinde pozitif yönde; TMN199, ADN712, GW2357, TMD139 ve ZN1018 genotiplerinde ise negatif yönde önemli olduğu belirlenmiştir.

Çizelge 10. Lif yeknesaklık oranı değerleri yönünden melezlerin ortalama değerleri, oluşan gruplar heterosis (\%) (Ht), heterobeltiosis ( \%) ( $\mathrm{Hb}$ ) ve özel uyum yeteneği (ÖUY)

Table 10. Average values of hybrids in terms of uniformity index, formed groups, heterosis (\%) (Ht), heterobeltiosis (\%) (Hb) and special combining ability (SCA)

\begin{tabular}{|c|c|c|c|c|c|}
\hline $\begin{array}{l}\text { Genotip no } \\
\text { Genotypes number }\end{array}$ & $\begin{array}{l}\text { Melezler } \\
\text { Hybrids }\end{array}$ & $\begin{array}{l}\text { Lif yeknesaklık oranı (\%) } \\
\text { Fiber uniformity index }\end{array}$ & $\begin{array}{c}\mathrm{Ht}(\%) \\
\mathrm{Ht}\end{array}$ & $\begin{array}{c}\mathrm{Hb}(\%) \\
\mathrm{Hb}\end{array}$ & $\begin{array}{l}\text { ÖUY etkileri } \\
\text { SCA effects }\end{array}$ \\
\hline 1 & $1 \times 5$ & $85,0 \mathrm{~h}-\mathrm{I}$ & -0.43 & $-0,66$ & $-0,333$ \\
\hline 2 & $1 \times 6$ & 85,1 g- ו & 0.02 & $-0,55$ & 0,167 \\
\hline 3 & $1 \times 7$ & 86,3 a-g & 0.29 & $-0,31$ & 0,042 \\
\hline 4 & $1 \times 8$ & 84,9 h-I & -0.95 & $-1,13$ & $-0,508$ \\
\hline 5 & $1 \times 9$ & 86,3 a-g & 0.80 & 0,78 & $0,625^{* *}$ \\
\hline 6 & $1 \times 10$ & 86,6 a-e & 0.25 & $-0,69$ & 0,167 \\
\hline 7 & $1 \times 11$ & 85,0 h-I & -0.55 & $-0,66$ & $-0,158$ \\
\hline 8 & $2 \times 5$ & 87,0 a-c & $2.09 * *$ & $2,07 * *$ & 1,195 \\
\hline 9 & $2 \times 6$ & 84,31 & -0.88 & $-1,02$ & $-1,038$ \\
\hline 10 & $2 \times 7$ & 87,2 a & $1.55^{*}$ & 0,73 & 0,504 \\
\hline 11 & $2 \times 8$ & 85,6 ו- 85 & 0.04 & $-0,35$ & $-0,280$ \\
\hline 12 & $2 \times 9$ & $85,3 \mathrm{f}-\mathrm{I}$ & -0.16 & $-0,39$ & $-0,813^{* *}$ \\
\hline 13 & $2 \times 10$ & $87,1 a-b$ & 0.73 & $-0,08$ & 0,262 \\
\hline 14 & $2 \times 11$ & $85,8 \mathrm{c}-\mathrm{h}$ & $1.19 *$ & 1,21 & 0,170 \\
\hline 15 & $3 \times 5$ & 84,9 h-ו & -0.72 & $-1,09$ & $-0,681^{* *}$ \\
\hline 16 & $3 \times 6$ & 85,9 b-h & 0.60 & 0,12 & $0,752 * *$ \\
\hline 17 & $3 \times 7$ & $85,7 d-h$ & -0.58 & $-1,04$ & $-0,806^{* *}$ \\
\hline 18 & $3 \times 8$ & $85,6 c-h$ & 0.00 & $-0,04$ & 0,211 \\
\hline 19 & $3 \times 9$ & 86,3 a-g & 0.66 & 0,54 & 0,411 \\
\hline 20 & $3 \times 10$ & 86,4 a-f & -0.12 & $-0,92$ & $-0,248$ \\
\hline 21 & $3 \times 11$ & $85,7 \mathrm{c}-\mathrm{h}$ & 0.18 & $-0,08$ & 0,361 \\
\hline 22 & $4 \times 5$ & 85,5 e-ו & 0.29 & 0,16 & $-0,181$ \\
\hline 23 & $4 \times 6$ & 85,4 ו-ו & 0.29 & 0,04 & 0,119 \\
\hline 24 & $4 \times 7$ & 86,9 a-d & 1.08 & 0,38 & 0,261 \\
\hline 25 & $4 \times 8$ & 86,4 a-f & 0.86 & 0,58 & 0,577 \\
\hline 26 & $4 \times 9$ & $85,8 \mathrm{c}-\mathrm{h}$ & 0.35 & 0,23 & $-0,223$ \\
\hline 27 & $4 \times 10$ & 86,6 a-e & 0.39 & $-0,65$ & $-0,181$ \\
\hline 28 & $4 \times 11$ & $85,2 \mathrm{f}-\mathrm{I}$ & -0.25 & $-0,27$ & $-0,373$ \\
\hline $\begin{array}{l}\text { Ortalamalar } \\
\text { (Means) }\end{array}$ & & 85.85 & & & \\
\hline CV (\%) & & 10,48 & & & \\
\hline LSD $(0.05)_{\text {Melezler (Hybrids) }}$ & & 14.40 & & & \\
\hline
\end{tabular}


Çizelge 10 'dan, melezlerin lif yeknesaklık oranı değerleri arasında istatiksel anlamda önemi bir farklılıklar saptanmıştır. En yüksek lif yeknesaklık oranı $2 \times 7$ melezinde, en düşük lif yeknesaklık oranı ise $2 \times 6$ melezlerinde belirlenmiştir. Aynı çizelgeden, heterosisin üç kombinasyonda (2X5, 2X11 ve 2X7), heterobeltiosisin ise bir kombinasyonda (2X5) pozitif yönde ve önemli olduğu saptanmıştır. $1 \times 9$ ve $3 \times 6$ melezlerinde ise özel uyum yeteneği değerinin pozitif yönde önemli olduğu bulunmuştur.

\section{Sonuçlar}

Yapılan Line $\mathrm{x}$ tester analiz sonucunda; kopma anındaki lif uzama oranı yönünden anaçlara ilişkin genel uyum yeteneği etkilerinin, FLASH, STV468, ADN712, TMN170 ve genotiplerinde pozitif yönden önemli olduğu, kısa lif içeriği yönünden GLORIA ve IPEK607 çeşitlerinde negatif yönde önemli olduğu görülmüştür. Lif yeknesaklık oranı yönünden anaçlardan FLASH ve UA48 genotiplerinde pozitif yönde önemli olduğu bulunmuştur. Kopma anındaki lif uzama oranı yönünden en ümitvar olan melez popülasyonların $1 X 8,2 X 8,4 X 5$ ve $4 X 9$, kısa lif içeriği yönünden ümitvar olan melez popülasyonlar; 3X7, 3X10, $1 X 10$ ve $1 X 7$ ve lif yeknesaklık oranı yönünden ümitvar olan melez popülasyonların ise $2 X 7$ ve 2X10'dir. Yukarıda bahsedilen lif kalite özelliklerinin eklemeli olmayan genler ile yönetildiği saptanmıştır. Hedef olarak belirlenen lif kalite özellikleri dikkate alınarak yukarıda anılan anaçlar melezleme çalışmalarında ebeveyn olarak kullanılmalıdır.

\section{Ekler}

Bu makale "Bazı Pamuk (Gosspium hirsutum L.) Genotiplerinin Çoklu Dizi (Line $x$ Tester) Melezlerinde Tarımsal ve Teknolojik Özelliklerin Kalıtımı" isimli doktora tezinden hazırlanmıştır. Bu çalışma, Tarımsal Araştırmalar ve Politikalar Genel Müdürlüğü ve Nazilli Pamuk Araştırma Enstitüsü Müdürlüğü tarafından desteklenmiştir. Bu kurumlara desteklerinden dolayı teşekkür ederiz.

\section{Kaynaklar}

Anonim, 2013. Tekstil sektörü ihracat performans değerlendirilmesi 2013 Yılı. ITKB Genel Sekreterliği AR\& GE ve mevzuat Şubesi Ocak 2014. Erişim 10.05.2015

http://www.akib.org.tr.Ifiles/downloads/Ekler/EkTekstil.pdf.

Anonim, 2017. Nazilli Pamuk Araştırma Enstitüsü İklim Verileri, Nazilli-Aydın.

Basbag, S. Ekinci, R ve Gencer, O. 2007. Combining ability and heterosis for earliness characters in line $\mathrm{x}$ tester population of Gossypium hirsutum L. Hereditas 144(5):185-190.

Başal, H., Ünay, A., Canavar and O., Yavas, I., 2009. Combining ability for fiber quality parameters and within-boll yield components in intraspecific and interspecific cotton populations. Spanish Journal of Agricultural Research, 7(2): 364- 74.

Boyacı, K., 2011. Bazı pamuk (Gosspium ssp.) genotiplerinin çoklu dizi (line xTester) melezlerinde tarımsal ve teknolojik özelliklerin kalıtımı üzerine Bir araştırma. Çukurova Üniversitesi Fen Bilimleri Enstitüsü, Tarla Bitkileri ABD, Doktora Tezi, Adana.

Chiang, M.S. and Smith, J.D., 1967. Diallel analysis of the inheritance of quantitative characters in grain sorghum 11. Gene action the number effective factor and Inheritability. Can. J. Gene Cytol., 9: 823-830.

EL-Feki., T.A., Abdel-Razık F.B., Gharab, M.A.M. and Emam, G.M.L., 1995. Heterosis and combining ability in top crosses of cotton. Beltwide Cotton Conferences, 1 : 588-589.

Falconer, D.S., 1981. Introduction to Quantitative Genetics. Logman Pub., Co., Newyork, NY, USA.

Fonseca, S. and Patterson, F.L., 1968. Hybrid vigour in seven parental diallel crosses in common wheat (Triticum aestivum L.). Crop Science, 2: 85-88.

Goyal, S. N. and Kumar, S. 1991. Combining ability for yield component and oil content in Sesame. Indian J. Genet.Plant Breeding 51: 311-314

Güvercin., R., 2016. Line x Tester (çoklu dizi) yöntemi ile geliştirilen bazı pamuk (Gossypium hirsutum L.) genotiplerinin Elbistan koşullarına uyum yetenekleriII; Lif Özellikleri. Yüzüncüyıl Üniversitesi Ziraat Fakültesi Tarım Bilimleri Dergisi, 26 (4): 603-613.

Hallauer, A. R. and Miranda Filho, J. B. 1981. Quantitative genetics in maize breeding. Lowa State Univ. Press.

Karademir, Ç., Karademir E., Ekinci R. and Gençer, O., 2009. Combining ability estimates and heterosis for yield and fiber quality of cotton in linextester design. Not. Bot.Hort. Agrobot. Cluj., 37 (2),228-233.

Karademir E. and Gencer, O., 2010. Combining ability and heterosis for yield and fibre quality properties in cotton (Gossypium hirsutum L.) obtained by half diallel mating design. Not. Bot. Hort. Agrobot. Cluj., 38 (1): 222-227.

Kempthorne, O., 1957. An Introduction to Genetic Statistics. John Wiley and Sons Inc., Newyork, U.S.A.

Lukonge, E.P., Labuschagne, M.T. and Herselman, L., 2007. Combining ability for yield and fibre characteristics in Tanzanian cotton germplasm. Euphytica, Int. J. Plant Breeding. 161: 383-389. 
Matzinger, D. F., 1963. Experimental estimates of genetics parameters and their applications in self-fertilizing plants. Statistical Genetics and Plant Breeding, p. 253-276, Washington.

Özcan, K. ve N. Açikgöz., 1999. A statistical program for population genetics. The Symposium of Computer Applications for Agricultural, 3-6 October Çukurova University, Adana-Turkey.

Saravanan, N.A., Ravikesaven, R. and Raveendran, T.S, 2010. Combining analysis for yield and fibre quality parameters in intraspecific hybrids of Gossypium hirsutum L. Electronic Journal of Plant Breeding, 1(4):856-863.

Senthilkumar, R., Ravikesaven, R., Punitha, D. and
Rajarratthinam, S., 2010. Genetic analysis in cotton. Electronic Journal of Plant Breeding, 1(4): 846-863.

Ünay, A., 1993. Pamukta (G. hirsutum L.) erkencilik ve bazı tarımsal özelliklerin kalıtımı üzerine araştırmalar. Trakya Üniversitesi Fen Bilimleri Enstitüsü Doktora Tezi, Edirne.

Yıldırım, M.B. ve İkiz, F., 1972. Uygulamalı Bitki Islahı. Ege Üniversitesi Ziraat Fakültesi Agronomi Genetik Kursu, Teksir No:2, Bornova-İzmir.

Zhu, Q., 1995. Advances in research and utilization of intervaritial hybrid vigor in upland cotton (G. hirsutum L.). Field Crops Abstract, 7(1): 8-11. 